Local Religion in Sixteenth-Century Spain 



\section{Local Religion in \\ Sixteenth-Century Spain}

William A. Christian, Jr.

PRINCETON UNIVERSITY PRESS

Princeton, New Jersey 
Copyright $(1) 1981$ by Princeton University Press Published by Princeton University Press, Princeton, New Jersey In the United Kingdom: Princeton University Press, Chichester, West Sussex

All Rights Reserved

Library of Congress Cataloging in Publication Data

Christian, William A. 1944-

Local religion in sixteenth-century Spain. Includes bibliographical references and index.

1. Spain-Religious life and customs.

2. Catholic Church in Spain-History.

I. Title.

BX1584.C49 282'.46 80-7513

ISBN 0-691-05306-5

ISBN 0-691-00827-2 (pbk.)

First Princeton Paperback printing, 1989

Publication of this book has been aided by a grant from the Paul Mellon Fund at Princeton University Press

This book has been composed in Linotype Janson

Princeton University Press books are printed on acid-free paper, and meet the guidelines for permanence and durability of the Committee on Production Guidelines for Book Longevity of the Council on Library Resources

Printed in the United States of America by Princeton Academic Press 